\title{
Sprawozdanie z ogólnopolskiej konferencji naukowej „Zawody zaufania publicznego - tradycje i wyzwania współczesności"
}

Refleksja o szczególnej roli zawodów zaufania publicznego obecna jest w literaturze niemal od dnia uchwalenia obowiązującej Konstytucji. Mimo tego wciąż szereg zagadnień związanych z tą problematyką pozostaje spornych lub - co najmniej - budzi wątpliwości. Jednym $z$ nich jest nawet sam sposób pojmowania idei zawodów zaufania publicznego, które wydają się być różnie definiowane nawet przez przedstawicieli konkretnych profesji zaufania publicznego. Zastanawiać musi przy tym, jak daleko rozbieżności w tym zakresie pogłębiają się wraz ze zróżnicowaniem poszczególnych zawodów zaufania publicznego? Czy w związku z tym np. lekarze, notariusze, radcowie prawni jednolicie rozumieją istotę i konsekwencje opisywania ich mianem „zawodu zaufania publicznego”? Czy przedstawiciele tych profesji podobnie postrzegają znaczenie i rolę charakterystycznych dlań instytucji, takich jak tajemnica zawodowa, a także jakie wyzwania stawia współczesność przed przedstawicielami zawodów zaufania publicznego?

$\mathrm{Na}$ te i podobne pytania starali się znaleźć odpowiedź uczestnicy ogólnopolskiej konferencji naukowej „Zawody zaufania publicznego - tradycje i wyzwania współczesności”, która odbyła się w dniach 15-16 kwietnia 2021 roku na Wydziale Prawa i Administracji Uniwersytetu Szczecińskiego. W organizację konferencji, oprócz społeczności akademickiej, włączyli się także przedstawiciele licznych samorządów zawodowych, w tym Okręgowa Izba Radców Prawnych w Szczecinie, Izba Komornicza w Szczecinie, Izba Notarialna w Szczecinie, Okręgowa Izba Lekarska w Szczecinie, a także Izba Adwokacka w Opolu. Zarazem patronat honorowy nad konferencją objęła Szczecińska Izba Pielęgniarek i Położnych oraz Samorząd Doradców Podatkowych. Ze względu na ograniczenia epidemiczne, organizatorzy konferencji zdecydowali, by wystąpienia poszczególnych panelistów miały charakter zdalny i były transmitowane dla wszystkich zainteresowanych przy wykorzystaniu platformy clickmeeting. Przyjęcie zdalnej formy konferencji umożliwiło udział w niej znacznego grona zainteresowanych. 
W ramach konferencji odbyło się łącznie 6 paneli tematycznych dotyczących takich problemów, jak: pojęcie zawodów zaufania publicznego; medyczne zawody zaufania publicznego; szczególne obowiązki osób wykonujących zawody zaufania publicznego; odpowiedzialność osób wykonujących zawody zaufania publicznego; samorządy zaufania publicznego oraz wyzwania i trudności funkcjonowania zawodów zaufania publicznego i ich samorządów. Prelegentami były przy tym zarówno osoby reprezentujące różnorodne samorządy zawodowe, w tym współorganizatorzy konferencji, jak i przedstawiciele 13 polskich i zagranicznych jednostek badawczych.

Konferencję otworzył referat prof. US dr. hab. Jerzego Ciapały, który w swoim referacie nakreślił konstytucyjne założenia regulacji statusu zawodów zaufania publicznego. Zwracając uwagę na pewną przypadkowość wprowadzenia do tekstu Konstytucji sformułowania „zawód zaufania publicznego”, podkreślił znaczną złożoność możliwych do odczytania norm art. 17 ust. 1 Konstytucji. Następnie referat wygłosił prof. UO dr hab. Jerzy Nikołajew, który, wychodząc od refleksji konstytucyjnej, postawił przed sobą niezwykle trudne zadanie zróżnicowania kategorii „osoba godna zaufania” oraz „osoba wykonująca zawód zaufania publicznego”. Kontekstem rozważań przedstawionych przez Prelegenta była przy tym rola kapelana więziennego na tle problemu wykonawstwa kary. Ostatnią osobą zabierającą głos w pierwszym panelu konferencji była prof. KUL dr hab. Monika Münnich, która w ramach swojego wystąpienia wyjaśniła, dlaczego zawód doradcy podatkowego winien być opisywany mianem „zawodu zaufania publicznego”.

Po krótkiej przerwie rozpoczął się drugi panel konferencji poświęcony bezpośrednio problematyce związanej z funkcjonowaniem tzw. medycznych zawodów zaufania publicznego. Punktem wyjścia dla dyskursu prowadzonego w tej części konferencji były rozważania dr Iwony Wrześniowskiej-Wal poświęcone ogólnej idei medycznych zawodów zaufania publicznego. Następny referat wygłosiła dr Aleksandra Klich, która scharakteryzowała szczególną funkcję, którą pełni tajemnica zawodowa w medycznych profesjach zaufania publicznego. Kolejno zaś swoje wystąpienia przedstawili mgr Natalia Wrzosek, dr Jacek Wiatrowski oraz dr Jolanta Pacian, którzy w swoich rozważaniach skupili się odpowiednio na postrzeganiu zawodu farmaceuty jako zawodu zaufania publicznego, zawodu lekarza jako zawodu zaufania publicznego oraz zawodu farmaceuty jako profesji zaufania publicznego w kontekście normatywnym przewinienia dyscyplinarnego.

Obrady w panelu dotyczącym szczególnych obowiązków osób wykonujących zawody zaufania publicznego zamykały pierwszy dzień konferencji. Panel ów otworzył referat dr. Rafała Wrzecionka, który skupił się na problemie różnic pomiędzy oczekiwaniami, a rzeczywistością w zakresie dotyczącym roli notariusza jako gwaranta bezpieczeństwa obrotu prawnego. Następnie głos zabrał przedstawiciel Samorządu Doradców Podatkowych mgr Michał Zając prezentujący swoje przemyślenia odnoszące się do możliwości zwolnienia przez klienta z obowiązku zachowania tajemnicy zawodowej. Szczególną rolę tajemnicy zawodowej podkreślił również kolejny prelegent, Wiceprezes Izby Notarialnej w Szczecinie notariusz Waldemar Chwiałkowski. W swoich rozważaniach sformułował tezę o roli tajemnicy zawodowej jako podstawy uznania notariusza za osobę zaufania publicznego. Kolejno głos zabrała mgr Angelika Koman, której wystąpienie koncentrowało się wokół zagadnie- 
nia klauzuli dobrych obyczajów jako przesłanki wykonywania zawodu radcy prawnego. Ostatni w tym dniu referat wygłosił mgr Michał Kiszkielis, charakteryzując zadania architekta jako zawodu zaufania publicznego na przykładzie odpowiedzialności przedstawicieli tej profesji za aspekty jakościowe, ekologiczne i ekonomiczne w architekturze miast.

Drugi dzień obrad otworzył panel dotyczący tematyki odpowiedzialności osób wykonujących zawody zaufania publicznego. Pierwszą panelistka była mgr Sylwia Zając, która wygłosiła referat o pojęciu i praktycznym znaczeniu kategorii „godności zawodu zaufania publicznego". Następny prelegent, mgr Bartosz Wilk, podzielił się natomiast własnymi rozważaniami dotyczącymi odpowiedzialności dyscyplinarnej radcy prawnego za reprezentowanie klienta nadużywającego prawa. Prezentowane rozważania były przy tym szczególnie istotne dla biorących udział w konferencji praktyków, gdyż nawiązywały one do jednego z rozstrzygnięć, które zapadły w Okręgowym Sądzie Dyscyplinarnym OIRP w Krakowie. Kolejny referat wygłosiła dr Marta Jasińska, która wygłosiła niezwykle ciekawy referat o zasadach odpowiedzialności porządkowej i dyscyplinarnej kuratorów zawodowych. Panel ów zakończył dr Paweł Niewięgłowski, który w swoich rozważaniach zarysował problem odpowiedzialności rzeczoznawcy majątkowego jako funkcjonariusza zaufania publicznego.

W kolejnym panelu uczestnicy konferencji skoncentrowali tematy swoich referatów wokół problemów związanych z samorządami zawodów zaufania publicznego. Panel ten otworzył referat dr Ewy Kowalewskiej, która podjęła się próby oceny charakteru prawnego składek samorządowych wpłacanych przez radców prawnych i aplikantów radcowskich. Jak słusznie podkreśliła prelegentka, zagadnienie to ma niezwykle istotne znaczenie praktyczne, gdyż w istocie determinuje właściwy tryb egzekucji stosownych świadczeń. Następnie głos zabrała dr Monika Kępa, która przybliżyła uczestnikom temat udziału przedstawicieli prawniczych samorządów zawodowych w regulowaniu zasad dostępu do zawodu. Kolejno swoje przemyślenia odnoszące się do współpracy przedstawicieli zawodów zaufania publicznego (na przykładzie doświadczeń Wojewódzkiej Komisji ds. Orzekania o Zdarzeniach Medycznych w Szczecinie) przedstawiła Przewodnicząca Szczecińskiej Izby Pielęgniarek i Położnych - dr Gabriela Hofman. Referat kończący opisywany panel wygłosiła natomiast Prezes Okręgowej Rady Lekarskiej w Szczecinie - dr Magdalena Wiśniewska, prezentując aktualny temat roli samorządu lekarskiego w utrzymaniu jakości świadczonych usług w czasach pandemii. Wystąpienie to spotkało się z dużym zainteresowaniem uczestników konferencji.

W ostatnim panelu konferencji kontynuowano zainicjowaną poniekąd przez dr Magdalenę Wiśniewską, problematykę współczesnych wyzwań i trudności funkcjonowania zawodów zaufania publicznego i ich samorządów. W referacie otwierającym tę część konferencji prof. UO dr hab. Dariusz Mucha skupił się na coraz częściej pojawiającym się problemie dotyczącym roli adwokatów i radców prawnych występujących jako obrońcy w sprawach karnych w zakresie zawierania porozumień procesowych w trybach konsensualnych. Następnie głos zabrał Dziekan Okręgowej Izby Radców Prawnych w Szczecinie - dr Przemysław Mijal, który scharakteryzował dylematy, obawy i perspektywy związane z wciąż powracającymi głosami dotyczącymi połączenia zawodów radcy prawnego i adwokata. Kolejny referat wygłosiła Wicedziekan Okręgowej Rady Adwokackiej w Opolu - adwokat 
Magdalena Koczur-Miedziejko, która skupiła uwagę uczestników na ocenie zawodów zaufania publicznego z perspektywy obywateli. Kontynuując rozważania związane ze współczesnymi wyzwaniami stawianymi zawodom zaufania publicznego, swoje przemyślenia zarysował Wiceprzewodniczący Izby Komorniczej w Szczecinie - komornik Remigiusz Wasiak. Ich istotą była tematyka egzekucji sądowej w czasie epidemii. Pozostając przy tematyce związanej z funkcjonowaniem prawniczych zawodów zaufania publicznego, prof. UW dr hab. Tadeusz Zembrzuski wygłosił referat, w którym podzielił się z uczestnikami konferencji refleksją o tradycjach i współczesnych wyzwaniach stawianych przed instytucją bezwzględnego przymusu adwokacko-radcowskiego. Następnie, nawiązując poniekąd do poprzedniego referatu, głos zabrała mgr Patricia Różańska-Ungur, która scharakteryzowała podstawowe problemy związane z zasięgiem korporacyjnego upoważnienia do zastępowania aplikanta. Ostatnim prelegentem konferencji był natomiast dr Szymon Kosatka, który podjął próbę odpowiedzi na pytanie o potrzebę sformułowania kodeksu etyki policji jako zawodu zaufania publicznego.

W tym miejscu nadmienić należy, że wszystkie referaty cieszyły się dużym zainteresowaniem uczestników konferencji, czego potwierdzeniem była burzliwa dyskusja po niemal każdym z paneli. Mając na względzie niezwykle obiecujące wyniki konferencji, jej organizatorzy zapowiedzieli powzięcie starań w przedmiocie wydania publikacji pokonferencyjnej, w której zebrane zostaną wszystkie wystąpienia.

\section{CYTOWANIE}

K. Dąbrowski, Sprawozdanie z ogólnopolskiej konferencji naukowej „Zawody zaufania publicznego tradycje i wyzwania wspótczesności”, Studia Administracyjne 2(14)/2021, 101-104, DOI: 10.18276/ sa.2021.14-09. 